\title{
Comparison of the effectiveness of non invasive and invasive therapy in the removal of viral warts of the foot skin
}

\author{
Porównanie skuteczności terapii nieinwazyjnych \\ i inwazyjnych w zabiegach usuwania \\ brodawek wirusowych skóry stóp
}

\begin{abstract}
The aim of this review was to compare the effectiveness of natural and invasive therapy in the removal of viral warts of the foot skin. A research was conducted based on 25 studies on wart removal with salicylic acid, pyruvic acid and formic acid, retinoids, 5-fluorouracil, phenol, occlusion, lasers: CO2, KTP, Nd:Yag, Er:Yag, pulse-dye, cryotherapy, electrocoagulation and surgical method. When comparing natural and invasive treatments, similar effectiveness was concluded, and the presented studies did not show any advantage one over the other.
\end{abstract}

Keywords: plantar warts, wart removal treatment, invasive treatment, non invasive treatment

\section{STRESZCZENIE}

Brodawki są częstym schorzeniem skóry, które może powodować ból i defekt kosmetyczny.

Celem pracy było porównanie skuteczności zabiegów nieinwazyjnych i inwazyjnych w terapii brodawek wirusowych skóry stóp. Uwzględniono 25 badań dotyczących usuwania brodawek za pomocą kwasu salicylowego, pirogronowego i mrówkowego, retinoidów, 5-fluorouracylu, fenolu, okluzji, laserów: $\mathrm{CO}_{2}$, KTP, Nd:Yag, Er:Yag, pulsacyjno-barwnikowego, krioterapii, elektrokoagulacji i chirurgicznego usuwania zmian. Wywnioskowano zbliżoną do siebie skuteczność, a przedstawione badania nie wykazały przewagi jednych zabiegów nad drugimi.

Słowa kluczowe: brodawki skóry stóp, terapia brodawek, terapie inwazyjne, terapie nieinwazyjne

\section{INTRODUCTION}

Warts are a common skin condition that can cause pain and a cosmetic defect. Infection most often occurs in public spaces, and the presence of wounds on the skin and an inappropriate immune response are the main factors contributing to their formation. Warts that persist for more than 2 years are called resistant warts.

The aim of most treatments is to remove infected skin cells. Unfortunately, it is not always possible to perform completely, and therefore this kind of treatment procedure is ineffective. In the scientific literature there are published many studies on the removal of foot skin warts by non-invasive and invasive methods, but no review has yet been published to compare these two methods of Human Papilloma Virus (HPV) lesions elimination. The aim of this study was to compare non-invasive and invasive treatment methods in the treatment of viral warts. 


\section{ETIOLOGY}

The Human Papilloma Virus (HPV) is a small DNA virus belonging to the PAPOVA group (papilloma, polyoma, vacuolating virus). There are about 100 types of viruses belonging to the genus HPV. Some of these types cause mild skin changes: warts, warts, genital warts. But other types of this virus can cause malignant tumors such as cervical cancer, laryngeal cancer and squamous cell carcinoma. The most common benign lesions are ordinary warts (epidermal papules of the color of the skin with an uneven and rough surface, 5-10 $\mathrm{mm}$ in diameter), flat warts, otherwise known as juvenile warts (flat lesions with a smooth surface, appear on the face, may have a linear pattern after scratch), genital warts (papules on the vulva or penis that tend to stick together and overgrow), and warts on the skin of the feet. It is assumed that the incubation period lasts approximately up to 4 months. Instead of destroying cells or deteriorating the condition of the cell with repeated inflammation, stimulation to proliferate comes to the fore. The infectivity rate of the virus is very high, and infection with one type does not leave permanent immunity against other types. The greatest incidence is among children and adolescents, and the contributing factors are individual susceptibility and impaired cellular immunity. The virus most often spreads in places of public use. Warts around the genitals and anus are transmitted through sexual contact. Children's genital warts may indicate sexual abuse, but they can also appear from self-infection or from contaminated bath water. Infection can also occur during childbirth, when the baby passes through the mother's birth canal [1-3].

\section{HPV-INDUCED SKIN CHANGES ON THE FEET}

Myrmecia warts are rare, deep skin lesions caused by HPV 1 (fig. 1). In the first phase, one eruption appears, then, as a result of the spreading of the lesions, new warts called satellites are formed. The changes penetrate deeply into the dermis, which causes inflammation and pain when walking. Myrmecia warts are most often found under the heads of the metatarsal bones and on the skin of the heels and toes. They are characterized by an uneven, excessively calloused structure with elements of breaking the continuity of fingerprints and the presence of capillaries in their structures. After the removal of the wart as a result of damage to the capillaries, intense bleeding occurs. These warts, due to their similarity and pain, are often confused with corns. Myrmecia are highly infectious warts, but they often resolve spontaneously, which is manifested by a change of color to brown-black [1-3].

Mosaic warts form numerous colonies superficially (fig. 2). They are created by joining together a large number of individual blooms. The factor causing the changes is the HPV 2 virus. The lumps are located in the superficial layers of the skin, thanks to which they do not cause inflammation

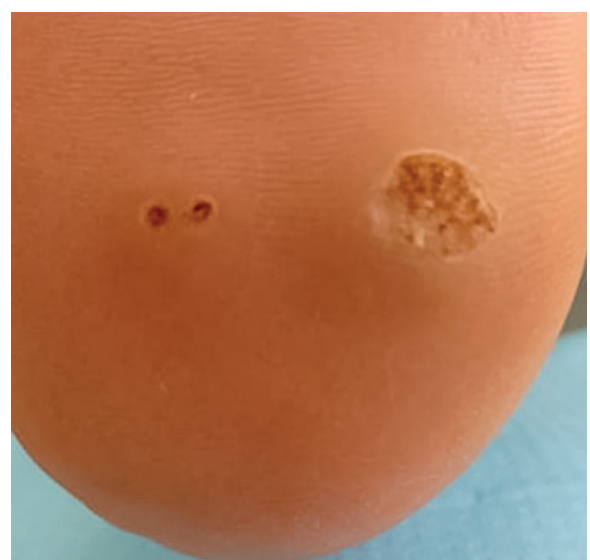

Fig. 1 Myrmecia warts on the heel

Source: Authors' own archive

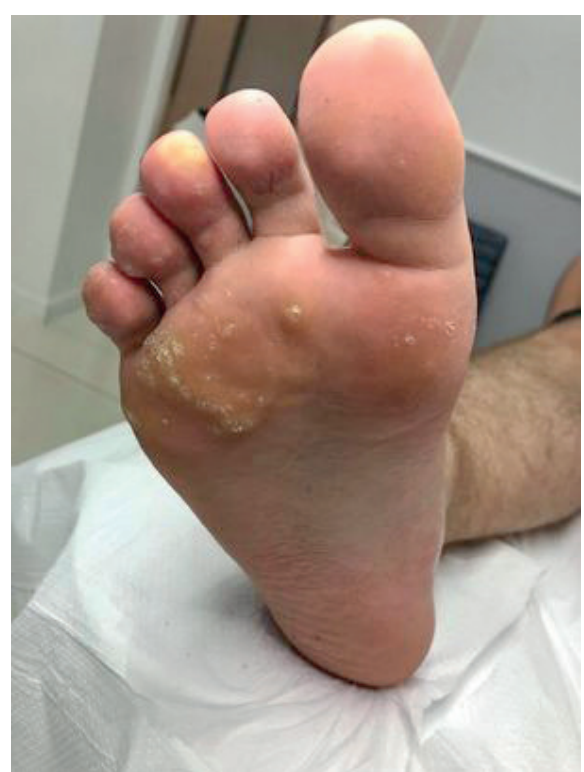

Fig. 2 Mosaic warts

Source: Authors' own archive

and are painless. Mosaic warts are usually found on the sole of the forefoot, heels, and toes, and can also appear on the hands and around the nails. They are flat, there are capillaries in them, there is also a break in the continuity of fingerprints, which makes it possible to distinguish them from prints. Mosaic warts are highly infectious, long-lasting and do not resolve on their own. A history of infection may result in a reduction in the body's immunity and recurrence of the disease $[1,2,4]$.

\section{FOOT SKIN WIRAL WART NON-INVASIVE THERAPIES ZOSTAWIĆ ZAŻÓŁCENIE}

\section{Organic acids}

- Salicylic acid is prepared in concentrations from $10 \%$ to $60 \%$. It is a keratolytic therapy which mechanism of action causes the slow destruction of virus-infected tissue 
and trigger an immune response. Side effects include occasional contact of healthy dermatitis with irritating acid. The warts should be cleaned of hyperkeratotic tissues, and then the preparation should be applied to the cleaned wart. The salicylic acid fluid is applied daily, and the patches are applied every 48 hours. The acids are especially recommended for use in children, and also for warts on the skin of the feet and sensitive parts of the body [5].

- Pyruvic acid is used as an exfoliant that is applied to the lesions with a cotton pad twice a day. After the procedure, the applied acid is not rinsed off, and the skin around the lesions should be protected with petroleum jelly [6, 7].

- Formic acid is a carboxylic acid, stronger than salicylic acid. It is applied to cleansed skin with a soaked cotton pad or stick. In a beauty salon formic acid is applied with a needle. The warts are punctured so as not to bleed. Healthy skin around the lesions is protected with petroleum jelly [8].

- 2. 5-fluorouracil (5-FU) blocks DNA synthesis and damages the dividing cells of the basal layer. Applied topically, it causes inflammation and sometimes erosions. Discoloration or, less frequently, hypopigmentation may occur if 5-FU is used for a long time [6].

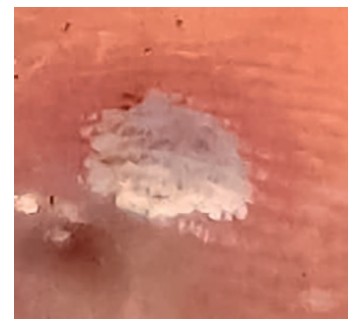

Fig. 3 Treatment of warts with an acid

Source: Authors' own archive

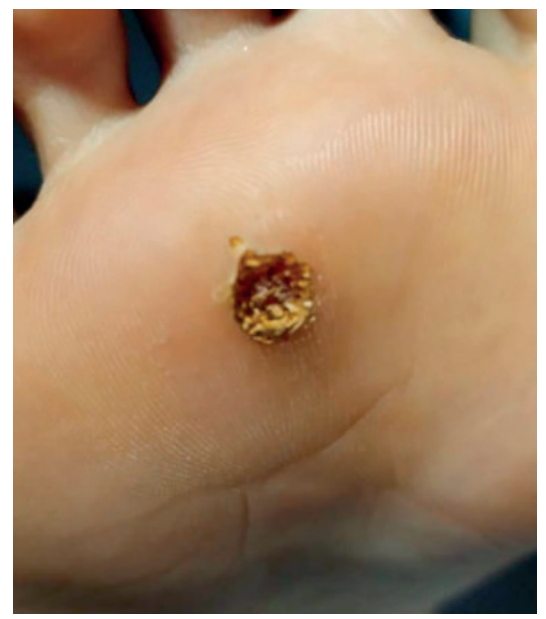

Fig. 4 Treatment of the wart with a laser

Source: Authors' own archive
- Phenol (carbolic acid) is a strongly corrosive substance. It causes a white scab on the surface of the skin and can penetrate deep into the tissue. Complications due to usage of phenol include burning, pain, erythema, discoloration, scarring, and infection. When lesions are eliminated with phenol on a large area of the skin, glomerulonephritis and arrhythmia may occur $[9,10]$.

\section{Occlusion therapy}

Occlusion therapy involves applying a lesion-sized piece of adhesive tape directly onto it. Then, after soaking in water, the wart is removed with a pumice stone. The mechanism of action remains unclear, but may include local irritation caused by glue or occlusion caused by adhesive tape [11, 12].

\section{INVASIVE THERAPIES}

\section{Laser therapy}

This way of wart treatment is based on photodermal or photomechanical destruction of the target tissue. Target structures absorb coherent monochrome light of a specified wavelength and fluence. The light energy is converted into heat energy, thus destroying the structure of the warts. Depending on the pulse duration and energy density, this may result in coagulation (photodermal effect) or blasting (photomechanical effect) of these structures.

- The $\mathrm{CO}_{2}$ laser emits infrared light $(10,600 \mathrm{~nm})$ which is absorbed by water, therefore it results in non-selective thermal tissue destruction. The focused CO2 laser beam can be used as a scalpel to cut out a wart [5]. Periungual and subungual lesions, which are difficult to remove by other methods, may be particularly suitable for this treatment. Side effects of this procedure in patients with normal immunity include postoperative pain, prolonged healing time and scarring [13].

- The KTP (potassium-titanium-phosphate) laser emits light with a length of $532 \mathrm{~nm}$ in green color. KTP lasers emit a beam in a continuous manner or as ultra-short pulses emitted at a very high frequency, perceived as a continuous wave $[14,15]$.

- The Nd: YAG laser emits infrared light with a wavelength of $1064 \mathrm{~nm}$ (fig. 4). The laser allows deeper penetration into tissues and reduces the risk of pigmentation changes. Due to the increased interaction of molecules with the laser, heat is distributed more evenly [16].

- The Er:YAG laser emits infrared radiation with a wavelength of 2,940 nm, which is absorbed 12 to 18 times more effectively by the superficial skin tissues containing water than the wavelength of $10,600 \mathrm{~nm}$ emitted by a $\mathrm{CO}_{2}$ laser. The Er: YAG laser has a smaller range of thermal damage, enabling more precise ablation with minimal scarring [5]. 
- A pulsed dye laser (PDL) emits yellow light with a wavelength of 585,595 or $600 \mathrm{~nm}$ that can selectively target oxyhemoglobin in the blood vessels. The dilated blood vessels in the papilla are "cauterized" when the target hemoglobin is heated. When blood flow to the wart is impaired, all or part of it becomes necrotic and peels off. Since blood vessels are selectively targeted, there is minimal damage to the surrounding tissue [17].

\section{Cryotherapy}

Liquid nitrogen at $-196^{\circ} \mathrm{C}$, supplied by a spray gun or cotton pads, is the most common method used in practice. Techniques vary by practitioner, with different freezing times, application methods, and intervals between treatments. It is common practice to freeze the tissue around the wart until a halo of frozen tissue appears, lasting for 5-30 seconds, depending on the location and size of the verruca. The treatment is repeated for 2-3 weeks until the warts are gone, up to about 6 treatments. Cryotherapy is a painful procedure, followed by blisters, hypo- or hyperpigmentation $[5,6]$.

\section{Electrocoagulation}

In electrosurgery direct current flows through the instrument that produces heat. The goal is to destroy the virus in the epidermis and not to damage the dermis to minimize the risk of scarring. A ball probe is selected for the procedure. After disinfecting the treated area, the excess of keratinized epidermis is removed with a scalpel or chisel, then the probe is moved along the lesion (fig. 5). The probe should be led over the lesion, because the contact of the probe with the skin prevents the conduction of electricity $[18,19]$

\section{Surgical excision of lesions}

Cutting out a wart is a common practice. It may involve curettage of the lesion - removal of skin lesions using a sterile surgical tool called a "spoon". Curettage with cauterization is a method in which in the first stage of the procedure the wart is cured, and then, thanks to the cauterization technique, the wound is sealed or a real excision procedure. Another method is an excision of the lesion with a scalpel or chisel. With each of these procedures, the lesion is removed with a small margin of healthy tissue [5, 17] (fig. 6].

\section{COMPARISON OF NON-INVASIVE \\ AND INVASIVE TREATMENTS \\ FOR ELIMINATION OF VIRAL WARTS}

Gibbs et al. compared 13 studies on the efficacy of salicylic acid at concentrations ranging from $15 \%$ to $60 \%$. Data collected from six placebo-controlled trials showed $75 \%$ effectiveness in the group receiving salicylic acid [20]. Monotherapy with 5-fluorouracil, glutaraldehyde, benzalkonium,

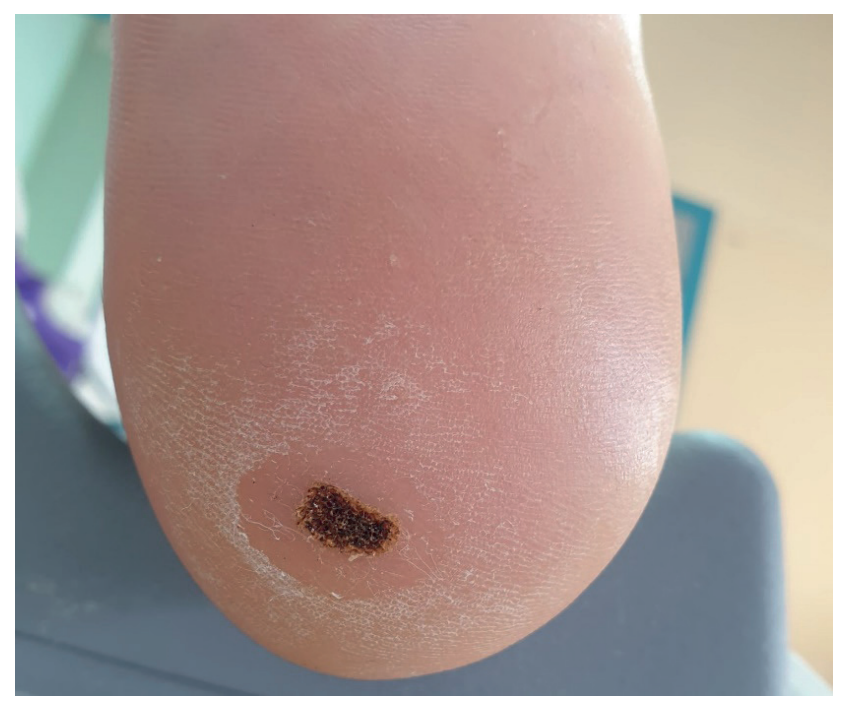

Fig. 5 Wart immediately after electrocoagulation Source: Authors' own archive

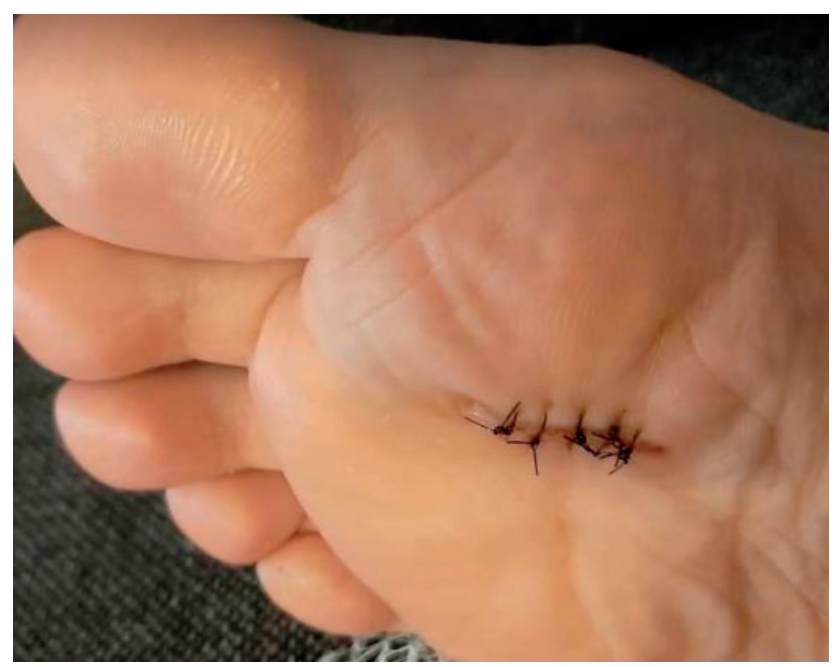

Fig. 6. The wart immediately after surgical removal Source: Authors' own archive

cryotherapy or podophylline did not turn out to be more effective than fluids containing salicylic acid [5, 20].

According to Shahmoradi et al, comparing the effectiveness of pyruvic acid and salicylic acid, the efficiency of pyruvic acid was $74.4 \%$, and that of salicylic acid - 72\%. Pain, burning sensation, scarring, discoloration and scabs were slight and did not differ significantly in the two groups [7].

In the studies conducted by Gerodimou et al., after completing 85\% formic acid therapy, 79 (56.8\%) of 139 patients participating in the study showed complete remission of lesions, 20 (28.8\%) partial remission, and 40 (14.4\%) \%) showed no response. A positive effect to surgery was defined as disappearance of warts, partial response as a reduction in the total number of warts, and no response as no change in wart formation. Formic acid caused first-degree chemical burns in 5 patients during the sixth week of 
treatment, leaving a ten-day interval until the next administration. Only 15 patients complained of the burning sensation [21].

A study conducted by Hursthouse showed 56.25\% effectiveness of 5-fluorouracil in removing warts. The main side effect was onycholysis, which occurred in eleven patients with fingertip lesions or periungual lesions. The only other side effect observed was patch sensitivity or irritation [22].

According to studies by Isçimen et al. the effectiveness of 5 -fluorouracil is $70 \%$. There were no clinically significant systemic or local side effects. Pain and burning were reported as immediate pain after application [23].

The aim of the research carried out by Banihashemi et al. was to evaluate and compare the effectiveness of cryotherapy and $80 \%$ phenol solution. The patients were randomized into two groups: 30 patients received cryotherapy treatments and 30 patients received $80 \%$ phenol once a week until complete clearance of the lesions or for a maximum of six weeks. Studies have shown that phenol is $70 \%$ effective in the treatment of warts [10].

Studies by de Haen et al. showed that occlusion therapy has little effect in removing warts. 103 children with common warts participated in the study. $15 \%$ of children reported side effects such as erythema, eczema and wounds [24]. The study showed that this therapy was effective in $16 \%$.

A study by Wenner et al. proved that the occlusive therapy was $21 \%$ effective. The research was carried out on a group of 90 people, 80 of whom completed the therapy. Patients were instructed to wear the occlusions for 7 days and remove it on the seventh evening. This process was repeated for 2 months or until the warts disappeared [25].

According to a survey conducted by Sloan et al. the success rate of $\mathrm{CO} 2$ laser treatments after 12 months was $64.1 \%$. The pain experienced during and after the procedure was described as moderate [26]

Research conducted by Gooptu et al. showed that the effectiveness of KTP laser treatments is $80 \%$. Most patients reported moderate discomfort during the procedure. Pain after surgery was minor. No changes were observed during or immediately after the procedure, although a few patients had erythema around each wart [27].

Studies by Kimura et al. demonstrated that the effectiveness of the Nd: YAG laser is $56 \%$. Due to the painfulness of the lesions, lidocaine was administered in 6 patients. No scars, pigment changes, or side effects were documented [28].

According to a survey by Smith et al., the percentage of removed warts after using the Nd: YAG laser was 69.8\%. Skin and tissue breakdown was observed in 4 out of 10 patients administered lidocaine to numb the surgical site. All skin lesions occurred in the laden part of the sole of the foot [29].

According to a study by Park et al., the Er: YAG laser was $75 \%$ effective. Before the procedure, anesthesia was obtained by local infiltration of $1 \%$ lidocaine with adrenaline solution 1: 100,000. Postoperative erythema occurred in all patients and disappeared after 2 months. No scars were observed after the laser treatment [30].

The research conducted by Wollin et al. showed $72.5 \%$ effectiveness of the Er: YAG laser. Most of the patients tolerated the procedure very well, although a slight pain in the process was reported a few times. No infection, pigmentation changes or scarring were described, even in the large treated areas [31].

Studies by Kenton-Smith et al. demonstrated that the PDL laser efficiency is $89.4 \%$. There was no recurrence of the wart at or near the surgical site after complete removal over a mean follow-up of 7.2 months (range 3-15). Some of the patients reported significant early postoperative pain, however most of them returned to work or normal activities immediately after surgery. PDL usually does not cause an open wound, which allows to avoid severe and prolonged pain, delayed wound healing and scarring [32].

According to the research of Borovoy et al. the effectiveness of the pulsed-dye laser is $79.9 \%$. Most patients describe the sensation of the flash pulsating as slight, shooting a rubber band against the skin, or a needle that is about to enter the skin (but it does not happen). Most patients reported slight to minimal discomfort immediately after the procedure. No one reported moderate to severe discomfort, also no infections were recorded. All patients were able to return to normal activity [33].

In the studies carried out by Bourke et al., the main purpose was to examine the effectiveness and time needed to remove viral warts by cryotherapy. 225 people were selected for treatments performed at intervals of 1, 2 or 3 weeks depending on the frequency of cryotherapy treatments. The indicators of the change in warts after 3 months were in line with the frequency of treatments. After 3 months, $43 \%$ recovery was noticed in the group of patients with treatments every week, $37 \%$ in the group with treatments every 2 weeks and $26 \%$ with treatments every 3 weeks. After 12 treatments, the clearance rates were similar in all three groups: $43 \%$ in the weekly group ( 3 months), $48 \%$ in the 2 -week group (6 months) and 44\% in the 3 -week group (9 months). Blisters and soreness were more common in patients undergoing weekly procedures. Soreness alone was reported in five patients attending weekly, five patients attending every 2 weeks, and none attending every 3 weeks. Only three patients were withdrawn from the study due to pain [34].

Research conducted by Berth-Jones et al. showed the effect of the second cycle of freezing on the lesion regression index after 3 months after cryotherapy of ordinary warts on the hands and feet. The efficiency was $57 \%$ for the single freeze technique and $62 \%$ for the double freeze technique. For plantar warts, the clearance rate was $41 \%$ for single freezing and $65 \%$ for double freezing. Cryotherapy was per- 
formed at 3-week intervals and patients were randomly assigned to one or two cycles of freezing [35].

The studies conducted by Ahmed et al. aimed to compare the method of removing warts with a spray gun with the method of soaking swabs with liquid nitrogen in terms of the disappearance of changes after 3 months. 207 patients were assessed. Treatments were performed every two weeks for up to 3 months. After 3 months the warts subsided in $47 \%$ in the swabs group and $44 \%$ in the cryo-spraying group [36].

One of the goals of the study by Awad et al. was to compare the effectiveness of cryosurgery and electrosurgery. The studies proved that electrocoagulation is $100 \%$ effective. All warts cleared up after one session. In the electrosurgical group ulceration was found in 5 patients and secondary infection occurred in 2 patients. There were no scars or discoloration [37].

The research carried out by Piskin et al. was aimed at the comparison of wart removal by infrared coagulation and electrocoagulation. The effectiveness of the electrocoagulation procedure was $68.2 \%$. The resolution of the lesions resulted in cosmetically acceptable scarring and pain in the healing stage was generally negligible. There was an exudate on the warts immediately after removal. The scab developed after 2 - 4 days on all lesions. Bacterial infection was observed on seven warts [38].

There are no published randomized, controlled trials using the technique of surgical excision of lesions on the feet. With success rates ranging from $65 \%$ to $85 \%$, scarring and recurrence are the most problematic consequences of this procedure. Both can occur in up to $30 \%$ of patients. The relapse is attributed to the activation of the Koebner phenomenon $[5,12]$.

\section{CONCLUSIONS}

1. Treatment of wart removal with acid and 5-fluorouracul is a safe and economical option that gives favourable results with few side effects.

2. Phenol requires more attention due to its toxicity and should not be used in large areas.

3. Occlusion therapy is ineffective and it is difficult for patients with plantar warts to wear the tape consistently due to excessive sweating and shoe friction. More research is needed to determine its true effectiveness.

4. HPV was found to be more responsive to heat treatment (hyperthermia) compared to cryotherapy - suggesting that laser ablation is more effective in eliminating the virus.

5. Electrocoagulation usually requires only one treatment and the clearance rate appears to be high.
6. Surgical excision of the plantar warts is not recommended as standard first-line therapy due to pain, possible relapse and the resulting plantar scar.

\section{SUMMARY}

Choosing the best wart therapy can be difficult, and relapse can appear randomly. Invasive methods are often painful and require long recovery periods, while non-invasive procedures usually depend on patient compliance and require long periods of use. The goal of therapy is to destroy the lesion in as few visits and as little pain as possible. Comparing non-invasive and invasive treatments, including: their benefits, their impact on the body and side effects, it can be concluded that their effectiveness is similar. The presented studies did not show any advantage of the effectiveness of non-invasive over invasive or invasive over non-invasive procedures.

\section{REFERENCES / LITERATURA}

1. Du Vivier A, Szubert A, eds. Atlas Dermatologii Klinicznej. Wrocław: Wydawnictwo Medyczne Urban \& Partner; 2005.

2. Jabłońska S, Chorzelski T. Choroby skóry. Dla studentów medycyny i lekarzy. Warszawa: Wyd. PZWL; 2001.

3. Rassner G, Szubert A, eds. Dermatologia. Podręcznik $i$ atlas. Wrocław: Wydawnictwo Medyczne Urban \& Partner; 1994.

4. Adamski Z, Kaszuba A. Dermatologia dla kosmetologów. Wyd. 2 zm. Wrocław: Wydawnictwo Elsevier Urban \& Partner; 2010.

5. Lipke MM. An Armamentarium of Wart Treatments. Clin Med Res. 2006;4(4):273-293. https://doi.org/10.3121/cmr.4.4.273

6. Sterling JC, Gibbs S, Haque Hassain SS, et al. British Association of Dermatologists' guidelines for the management of cutaneous warts 2014. Br J Dermatol. 2014;171(4):696-712. https://doi.org/10.1111/bjd.13310

7. Shahmoradi Z, Assaf F, Al Said H, et al. Topical pyruvic acid (70\%) versus topical salicylic acid (16.7\%) compound in treatment of plantar warts: A randomized controlled trial. Adv Biomed Res. 2015;4:113. https://doi.org/10.4103/2277-9175.157833

8. Bhat RM, Vidya K, Kamath G. Topical formic acid puncture technique for the treatment of common warts. Int J Dermatol. 2001;40(6):415-419. https://doi.org/10.1046/j.1365-4362.2001.01242.x

9. Campbell MA. Non-genital Warts: A Review of Current Treatments Part II. Pract Dermatol. 2010;7:35-42.

10. Banihashemi M, Pezeshkpoor F, Yazdanpanah MJ, et al. Efficacy of 80\% phenol solution in comparison with cryotherapy in the treatment of common warts of hands. Singapore Med J. 2008;49(12):1035-1037.

11. Mulhem E, Pinelis S. Treatment of Nongenital Cutaneous Warts. Am Fam Physician. 2011;84(3):289-293.

12. Vlahovic TC, Khan MT. The Human Papillomavirus and Its Role in Plantar Warts. A Comprehensive Review of Diagnosis and Managment. Clin Podiatr Med Surg. 2016;33(3):337-353.

https://doi.org/10.1016/j.cpm.2016.02.003

13. Sterling JC, Handfield-Jones S, Hudson PM. Guidelines for the management of cutaneous warts. Br J Dermatol. 2001;144(1):4-11. https://doi.org/10.1046/j.1365-2133.2001.04066.x

14. Malinowska S, Mlosek RK. Lasery i IPL - źródła światła stosowane w gabinetach kosmetologicznych i medycyny estetycznej. Kosmetologia Estetyczna. 2016;5:543-548.

15. Burdzy D, Ozga D, Kosydar-Bochenek J, et al. Zastosowanie laserów w terapii wybranych problemów skórnych. Przegląd metod. Kosmetologia Estetyczna. 2017;6:645-652.

16. Hsu VM, Aldahan AS, Tsatalis JP, et al. Efficacy of Nd:YAG laser therapy for the treatment of verrucae: a literature review. Lasers Med Sci. 2017;32(5):1207-1211. https://doi.org/10.1007/s10103-017-2219-5 
17. Brodell RT, Johnson SM. Warts Diagnosis and Management: An Evidence-based Approach. Warszawa: Wydawnictwo Taylor \& Francis Group; 2003.

18. Campbell MA. Non-genital Warts: A Review of Current Treatments. Pract Dermatol. 2010;7:42-48.

19. Mahrle G, Witiko A. Surgical Treatment of Recalcitrant Warts. J Dermatol Surg Oncol. 1983;9(6):445-450.

https://doi.org/10.1111/j.1524-4725.1983.tb00833.x

20.Gibbs S, Harvey I, Sterling J, et al. Local treatments for cutaneous warts. Cochrane Database Syst Rev. 2003;3:46. https://doi.org/10.1002/14651858.CD001781

21. Gerodimou M, Gerochristou M, Emmanouil G, et al. Efficacy of topical $85 \%$ formic acid solution in the treatment of warts. Our Dermatol Online. 2020;11(4):363-366.

22. Hursthouse MW. A controlled trial on the use of topical 5-fluorouracil on viral warts. Br J Dermatol. 2006;92(1):93-96. https://doi.org/10.1111/j.1365-2133.1975.tb03039.x

23. Iscimen A, Aydemir E, Goksungur N, et al. Intralesional 5-fluorouracil, lidocaine and epinephrine mixture for the treatment of verrucae: a prospective placebo-controlled, single-blind randomized study. J Eur Acad Dermatol Venereol. 2004;18(4):455-458. https://doi.org/10.1111/j.1468-3083.2004.00984.x

24. De Haen M, Spigt MG, van Uden CJT, et al. Efficacy of Duct Tape vs Placebo in the Treatment of Verruca Vulgaris (Warts) in Primary School Children. Arch Pediatr Adolesc Med. 2006;160(11):1121-1123. https://doi.org/10.1001/archpedi.160.11.1121

25. Wenner R, Askari SK, Cham PMH. Duct Tape for the Treatment of Common Warts in Adults: A Double-blind Randomized Controlled Trial. Arch Dermatol. 2007;143(3):309-313. https://doi.org/10.1001/archderm.143.3.309

26. Sloan K, Haberman H, Lynde CW. Carbon Dioxide Laser-Treatment of Resistant Verrucae Vulgaris: Retrospective Analysis. J Cutan Med Surg. 1998;2(3):142-145. https://doi.org/10.1177/120347549800200306

27. Gooptu C, James MP. Recalcitrant viral warts: results of treatment with the KTP laser. Clin Exp Dermaol. 1999;24(2):60-63. https://doi.org/10.1046/j.1365-2230.1999.00418.x

28. Kimura U, Takeuchi K, Kinoshita A, et al. Long-pulsed 1064-nm neodymium:yttrium-aluminum-garnet laser treatment for refractory warts on hands and feet. J Dermatol. 2014;41(3):252-257. https://doi.org/10.1111/1346-8138.12411

29. Smith EA, Patel SB, Whiteley MS. Evaluating the success of Nd: YAG laser ablation in the treatment of recalcitrant verruca plantaris and a cautionary note about local anaesthesia on the plantar aspect of the foot. J Eur Acad Dermatol Venereol. 2015;29(3):463-467. https://doi.org/10.1111/jdv.12579

30. Jae-Hong P, Eul-Sang H, Soo-Nam K, et al. Er:YAG Laser Treatment of Verrucous Epidermal Nevi. Dermatol Surg. 2004;30(3):378-381. https://doi.org/10.1111/j.1524-4725.2004.30104.x

31. Wollina U, Konrad H, Karamfilov T. Treatment of common warts and actinic keratoses by Er:YAG laser. J Cutan Laser Ther. 2001;3(2):63-66. https://doi.org/10.1080/146288301753377852

32. Kenton-Smith J, Tan ST. Pulsed dye laser therapy for viral warts. $\mathrm{Br}$ J Plast Surg. 1999;52(7):554-558.

https://doi.org/10.1054/bjps.1999.3121

33. Borovoy M, Borovoy M, Elson L, et al. Flashlamp pulsed dye laser (585 nm). Treatment of resistant verrucae. J Am Podiatr Med Assoc. 1996;86(11):547-550. https://doi.org/10.7547/87507315-86-11-547

34. Bourke JF, Berth-Jones J, Hutchinson PE. Cryotherapy of common viral warts at intervals of 1, 2 and 3 weeks. Br J Dermatol. 1995;132(3):433436. https://doi.org/10.1111/j.1365-2133.1995.tb08678.x

35. Berth-Jones J, Bourke J, Eglitis H, et al. Value of a second freezethaw cycle in cryotherapy of common warts. Br J Dermatol. 1994; 131(6):883-886.

https://doi.org/10.1111/j.1365-2133.1994.tb08594.x

36. Ahmed I, Agarwal S, Ilchyshyn A, et al. Liquid nitrogen cryotherapy of common warts: cryo-spray vs. cotton wool bud. Br J Dermatol. 2001;144(5):1006-1009. https://doi.org/10.1046/j.1365-2133.2001.04190.x

37. Awad SM, El-Badawy O, Abou-Taleb DAE. Efficacy of Intralesional Cryosurgery in the Treatment of Multiple Extragenital Cutaneous Warts. A Randomized Controlled Study. Dermatol Surg. 2020;46(8):8-15. https://doi.org/10.1097/DSS.0000000000002217

38. Piskin S, Aksoz T, Gorgulu A. The Treatment of Common Warts with Infrared Coagulation. J Dermatol. 2004;31(12):989-992. https://doi.org/10.1111/j.1346-8138.2004.tb00642.x 